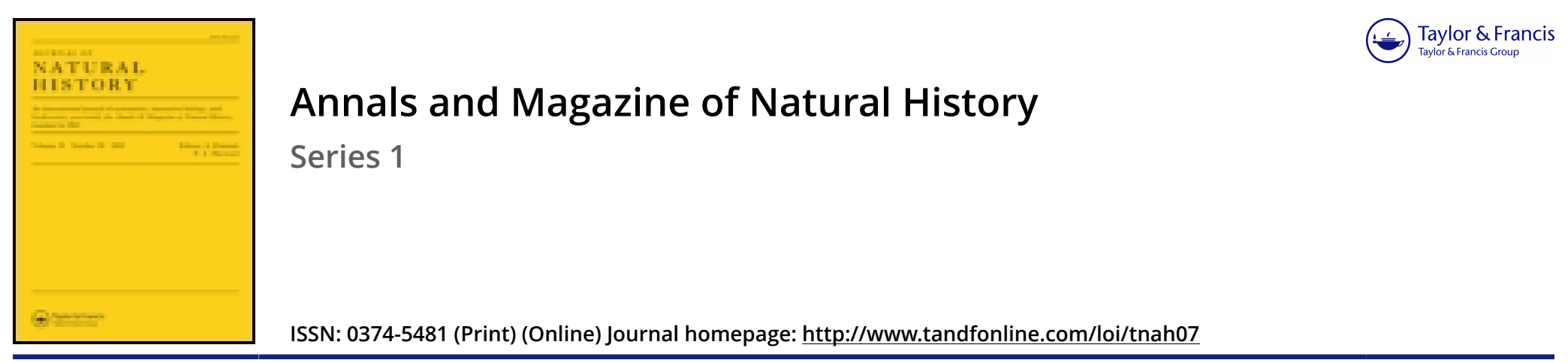

\title{
New species of fossil bats
}

\section{H. de Meyer}

To cite this article: M. H. de Meyer (1846) New species of fossil bats, Annals and Magazine of Natural History, 17:114, 450-450, DOI: 10.1080/037454809495855

To link to this article: http://dx.doi.org/10.1080/037454809495855

册Published online: 16 Dec 2009.

Submit your article to this journal

LII Article views: 1

Q View related articles ¿ 
lets go until forced to do so. I placed a sand lizard within its reach, which it instantly seized, and retained its hold for upwards of two hours, although for more than half that time it was suspended from it.

Before concluding, permit me to mention that the following reptiles have been found by me near Liverpool since August last : $Z 00$ toca vivipara, Lacerta agilis, Natrix torquata, Vipera communis, Triton palustris, T. aquaticus, T. vulgaris, Rana temporaria, Bufo vulgaris.

I remain, yours very respectfully, W. WELLS.

New species of Fossil Bats. By M. H. De MeYer.

Cheiroptera have but rarely been found fossil in the tertiary formations. Of this family, in the deposits anterior to the diluvian epoch, only the Vespertilio parisiensis of the schists of Montmartre was known, a single individual of which is preserved in the Museum of Paris; and two small teeth found in the eocene sand of Kyson, and referred with doubt by Prof. Owen to the genus Vespertilio. The species indicated by Karg, at CEningen, appears to be very uncertain, and the original specimen has not been discovered again. Hermann de Meyer has detected at Weisenau, amongst a considerable mass of fragments of bones, some belonging to two Cheiroptera. They consist of one half of the right lower jaw, in which, although the teeth are wanting, the alveoli are sufficiently well preserved to give an idea of the dental system; of three humeri, of which two are left and one right, which show the existence of two species, and prove even probably a generic difference between them; lastly, of one half of a radius which likewise can only belong to a Cheiroptera. These two species differ from that of Montmartre, and H. de Meyer has designated them under the name of Vespertilio precox and V. insignis, until their generic affinities are definitely fixed._Leonhard und Bronn's Jahrbuch, 1845, p. 798.

\section{Does Magnetism influence the Circulation in Chara? \\ By M. Dutrochet.}

In some experiments made in the year 1837, M. Dutrochet proved that electric currents only affect the circulation of Chara by their action as exciting causes. The movement of the fluid is only arrested for a few minutes and then recommences, often with greater rapidity than before, as the equilibrium between the electric and vital forces is restored. This action is exactly analogous to that of hot water or solution of common salt.

M. Dutrochet has recently submitted Chara to the influence of a large electro-magnet, capable of supporting a weight of about 4000 pounds. The stem of Chara was placed a little in front of a plane passing vertically through the poles of the horse-shoe magnet, but quite within the magnetic influence. Careful observation at the moment of establishing the electric current in the coil, proved that the speed of the circulation was unaltered. Left thus for ten minutes, all remained as before-no influence was manifested. The 